\title{
An analysis of the literature on humanitarian logistics and supply chain management: paving the way for future studies
}

\author{
Charbel José Chiappetta Jabbour ${ }^{1,7}$ • Vinicius Amorim Sobreiro² \\ Ana Beatriz Lopes de Sousa Jabbour ${ }^{3,7}$. Lucila Maria de Souza Campos ${ }^{4}$. \\ Enzo Barberio Mariano ${ }^{5}$. Douglas William Scott Renwick ${ }^{6}$
}

(C) The Author(s) 2017. This article is an open access publication

\begin{abstract}
The area of disaster management has become increasingly prominent in a context of frequent political, religious change and conflict, and within it, the field of knowledge on humanitarian logistics and supply chain management (HLSCM) has attracted attention from a variety of stakeholders, such as scholars, practitioners and policy makers. Consequently, humanitarian logistics and supply chain research has seen a significant increase in the quan-
\end{abstract}

$凶$ Charbel José Chiappetta Jabbour

c.j.chiappettajabbour@stir.ac.uk

Vinicius Amorim Sobreiro

sobreiro@unb.br

Ana Beatriz Lopes de Sousa Jabbour

ana.jabbour@strath.ac.uk

Lucila Maria de Souza Campos

lucila.campos@ufsc.br

Enzo Barberio Mariano

enzo@feb.unesp.br

Douglas William Scott Renwick

douglas.renwick@ntu.ac.uk

1 Stirling Management School, University of Stirling, Stirling FK9 4LA, Scotland, UK

2 Department of Management, University of Brasília, Campus Darcy Ribeiro, Brasília, Federal District 70910-900, Brazil

3 Faculty of Engineering, University of Strathclyde, Glasgow, Scotland, UK

4 Production Engineering and Systems Department, Federal University of Santa Catarina, Campus Universitário Trindade, Florianópolis 88040-900, Brazil

5 Production Engineering Department, São Paulo State University (UNESP), Av. Eng. Luiz Edmundo C. Coube 14-01, Bauru, São Paulo 17033-360, Brazil

6 College of Business Law and Social Sciences, Nottingham Business School, Nottingham Trent University, 50 Shakespeare Street, Nottingham NG1 4FQ, UK

7 Montpellier Business School, Montpellier Research in Management, 2300 avenues des Moulins, 34185 Montpellier Cedex 4, France 
tity of works emerging, particularly journal articles. In this context, we aim to systematize the selected contemporary literature on humanitarian logistics and supply chain management. After identifying the relevant literature on Scopus and Web of Science, we chart a systematization of this body of knowledge by applying a system of codes and classifications to it. Based on research gaps found, we propose an original research agenda for further developing the humanitarian logistics and supply chain management field, as suggested avenues for future research.

Keywords Humanitarian logistics · Humanitarian supply chain · Humanitarian operations management $\cdot$ Sustainable operations $\cdot$ Disaster relief $\cdot$ Sustainable supply chain

\section{Introduction}

In this article, we aim to systematize selected contemporary literature on humanitarian logistics and humanitarian supply chain management (HLSCM), which has attracted a considerable amount of attention from scholars, practitioners and policy makers alike (Kovacs and Spens 2010). Rising interest in this field has been justified by a myriad of humanitarian challenges that society has faced over the past few years (Dubey and Gunasekaran 2015), examples of which include natural disasters and armed conflicts among others. As the subject of humanitarian logistics and supply chain gains more relevance the literature surrounding it has significantly increased, meaning a systematization of this literature now seems appropriate, as does identifying research gaps for future studies.

Consequently, the contribution of this article is to provide a systematization of selected contemporary works in the relevant literature on humanitarian logistics and supply chain that have been published by journals indexed in Scopus and Web of Science. Inspired by procedures adopted by highly cited literature reviews (e.g. Lage Junior and Godinho Filho 2010), this paper delivers:

- An identification of the main articles on the field of humanitarian logistics and supply chain indexed in Scopus and Web of Science;

- A classification of the relevant literature above based on a variety of characteristics; and

- An original research agenda for future studies, based on gaps found in the current stateof-the-art body of knowledge.

This article is organized as follows. After our introduction (Sect. 1), we present the research methods we used (Sect. 2) to frame the classification and coding system we used to scrutinize the relevant literature (Sect. 3). We then briefly detail our conceptual background in Sect. 4, while Sect. 5 sheds light on our results and subsequent discussion. We conclude in Sect. 6 by presenting an original, new research agenda forward in this field.

\section{Research methods}

A literature review has as its main objective to show the central structures of a subject or topic, with the aim of identifying research progress that has been made, as well as literature gaps that remain (Hart 1999; Baker 2000). In this context, we use and apply the methodology and steps proposed by Lage Junior and Godinho Filho (2010) and subsequently tested by Jabbour (2013) and Mariano et al. (2015) in our literature review. As such, we observe the following steps: 
- First: Identifying the main articles available on the subject in academic databases and considering the principal keywords related to the topic;

- Second: Screening the articles found in the first step in order to eliminate articles outside the subject area;

- Third: Developing and applying a classification system to identify central structures of the subject or topic considered;

- Fourth: Providing a literature review using the classification system elaborated in the third step above; and

- Fifth: Identifying gaps, opportunities and challenges regarding future research studies in this area.

For our first step, the main articles about humanitarian logistics we identified during August and September 2016 contained the keywords of "Logistics", "Supply Chain Management" and "Humanitarian" in the academic databases of Scopus and Web of Science. We chose the two databases because they both compile data about abstracts and citations of scientific journals, books and conference proceedings from fourteen of the largest publishers in the world. Here, we used different combinations of keywords to increase the scope and reach of our search. After this first step, we performed screening with the objective of identifying all articles outside of the scope of our identified topics. Consequently, our final database comprised 87 articles that, in turn, were classified based on the coding presented in Table 1, and described in the following section. Finally, taking into account our proposed coding, a descriptive statistic was used to identify the main gaps remaining from the literature, as shown in Sect. 5.

\section{Classification and coding}

Considering the method proposed by Lage Junior and Godinho Filho (2010) and Jabbour (2013), we defined a set of classifications to organize the identified articles into specifics groups. This classification set included eight categories numbered from 1 to 8 , and for each of them a group of coding was defined and used via letters from A to K. For example, a code of $2 \mathrm{~B}$ means that this article is classified in section B of category 2, and such articles could be classified in one or more our categories above. Taking such points into account, our eight classifications are briefly defined below as:

- Classification 1-Economic context: The degree of economic maturity of the countries in which the study occurred, coded from $A$ to $D$;

- Classification 2-Focus: The main theme considered in any study, coded from A to C;

- Classification 3-Method: The method used in a study, classified and coded from A to $\mathrm{K}$;

- Classification 4-Type of disaster: The different forms and durations of disasters considered in the study analysed, coded from A to E;

- Classification 5-Phase of the disaster relief: The more important phase of disaster relief addressed in a study, coded from A to D;

- Classification 6-Type of humanitarian organization: The types of humanitarian organization addressed by the author of the study analysed, coded from A to E;

- Classification 7-Region of authorship: The region of authorship, coded from A to E. This category also considers whether there is a significant volume of academic output for a specific region by the authors; and 
Table 1 Classifying and coding

\begin{tabular}{|c|c|c|}
\hline Classification & Meaning & Coding \\
\hline 1 & Economic context & $\begin{array}{l}\text { 1A-Mature economy } \\
\text { 1B-Non-mature economy } \\
\text { 1C-Mixed } \\
\text { 1D-Not applicable }\end{array}$ \\
\hline 2 & Focus & $\begin{array}{l}\text { 2A-SCM } \\
\text { 2B-Logistics } \\
\text { 2C-Both }\end{array}$ \\
\hline 3 & Method & $\begin{array}{l}\text { 3A-Qualitative } \\
\text { 3B-Quantitative } \\
\text { 3C-Conceptual } \\
\text { 3D-Modelling } \\
\text { 3E-Survey } \\
\text { 3F-Others quantitative approaches } \\
\text { 3G-Single case study } \\
\text { 3H-Multiple case study } \\
\text { 3I-Interviews } \\
\text { 3J-Others qualitative approaches } \\
\text { 3K-Mixed methodology }\end{array}$ \\
\hline 4 & Type of disaster & $\begin{array}{l}\text { 4A-Man-made with slow-onset } \\
\text { 4B-Man-made with sudden-onset } \\
\text { 4C-Natural with slow-onset } \\
\text { 4D-Natural with sudden-onset } \\
\text { 4E-Not applicable }\end{array}$ \\
\hline 5 & Phase of the disaster relief & $\begin{array}{l}\text { 5A-Preparation and prevention } \\
\text { 5B-Immediate response } \\
\text { 5C-Reconstructing } \\
\text { 5D-Not applicable }\end{array}$ \\
\hline 6 & Type of humanitarian organization & $\begin{array}{l}\text { 6A-Supranational aid agencies } \\
6 \mathrm{~B}-\text {-Governmental organization } \\
6 \mathrm{C}-\text { Big international non-governmenta } \\
\text { organizations (BINGOs) } \\
\text { 6D-Smalls national non-governmental } \\
\text { organization (NGOs) } \\
\text { 6E-Not applicable }\end{array}$ \\
\hline 7 & Region of authorship & $\begin{array}{l}\text { 7A-America } \\
\text { 7B-Europe } \\
7 \mathrm{C} \text {-Asia } \\
\text { 7D-Africa } \\
\text { 7E-Oceania }\end{array}$ \\
\hline 8 & Region of disaster & $\begin{array}{l}\text { 8A-America } \\
\text { 8B-Europe } \\
8 \mathrm{C} \text {-Asia }\end{array}$ \\
\hline
\end{tabular}


Table 1 continued

\begin{tabular}{lll}
\hline Classification & Meaning & Coding \\
\hline & 8D-Africa \\
& $8 \mathrm{E}-$ Oceania \\
& $8 \mathrm{~F}-$ Not applicable \\
\hline
\end{tabular}

- Classification 8-Region of disaster: The region where the disaster occurred, coded from A to $\mathrm{F}$.

All the descriptions of our classifications and codes are shown in Table 1, and the research articles considered in our literature review are detailed in Table 2.

\section{A brief conceptual foundation of humanitarian logistics and supply chains}

Humanitarian supply chain management (HLSCM) is intimately tied to the broader context of disaster management which itself is a subject of much contemporary popularity. For example, recent works such as Yang et al. (2014), have used Data Envelopment Analysis to build an emergency response network for earthquakes, Anparasan and Lejeune (2017) have proposed a model of emergency responses to epidemics that can be used in countries that have limited resources, and Sushil (2017) has proposed the use of a qualitative and interpretative framework called SAP-LAP in the context of disaster management.

Two subjects in HLSCM can be considered very important as they have been widely studied, namely: humanitarian supply chains (HSC) and humanitarian logistics (HL). During the past decade, HSC has received greater attention among academics and practitioners (Kovacs and Spens 2010), and many HSC works are trying to better explore this subject. Examples include: coordination of HSC (Balcik et al. 2010; Akhtar et al. 2012), specifically studying the drivers and barriers of the coordination of HSCs (Kabra and Ramesh 2015b; Kabra et al. 2015), and developing frameworks to improve HSC implementation (John et al. 2012).

However, it has been observed from the literature, that most HSCs are unstable, unpredictable, and slow to respond to the needs of affected people (Yadav and Barve 2015), especially when related to those disasters. Such disasters not only disturb the normal functioning of society, but can also leave huge and negative impacts on the people directly or indirectly impacted by them. It is not possible to predict natural disasters, but actions can be taken to deal with such complex crises and reduce the impact of natural disasters on people and society (Kovács and Spens 2007; Kabra and Ramesh 2015b; Kabra et al. 2015).

Wassenhove (2006) defines a disaster as a "disruption that physically affects a system as a whole and threatens its priorities and goals", and considers HSC a central point for at least three reasons, as HSC: (i) serves as a bridge between disaster preparedness and response, between procurement and distribution; (ii) is crucial to the effectiveness and speed of response for major humanitarian programs, such as health, food, shelter, water and sanitation; and, (iii) can be one of the most expensive parts of relief efforts and operations, and thus deserves special attention.

In this sense, a very important concept for HSC is resilience, which is the ability of a supply chain to absorb the impacts of any rupture caused by a disaster and to recover from it. Here, DuHadway et al. (2017) developed a framework that allows us to understand the risks 
Table 2 Coding of the studies considered (Part 1)

\begin{tabular}{|c|c|c|c|c|c|c|c|}
\hline \multirow{2}{*}{$\frac{\text { Studies }}{\text { Kovács and Spens (2007) }}$} & \multicolumn{7}{|c|}{ Categories } \\
\hline & $1 \mathrm{D} 2 \mathrm{~B}$ & $3 \mathrm{C}$ & $4 \mathrm{E}$ & $5 \mathrm{D}$ & $6 \mathrm{E}$ & $7 \mathrm{~B}$ & $8 \mathrm{~F}$ \\
\hline Apta (2009) & $1 \mathrm{D} 2 \mathrm{~B}$ & $3 \mathrm{C}$ & $4 \mathrm{E}$ & $5 \mathrm{D}$ & $6 \mathrm{E}$ & $7 \mathrm{~A}$ & $8 \mathrm{~F}$ \\
\hline Blecken et al. (2009) & $1 \mathrm{D} 2 \mathrm{~A}$ & $3 \mathrm{C}$ & $4 \mathrm{E}$ & $5 \mathrm{~A}$ & $6 \mathrm{E}$ & $7 \mathrm{~B}$ & $8 \mathrm{~F}$ \\
\hline Carroll and Neu (2009) & $1 \mathrm{D} 2 \mathrm{C}$ & $3 \mathrm{C}$ & $4 \mathrm{E}$ & $5 \mathrm{~A}$ & $6 \mathrm{~A}$ & $7 \mathrm{~B}$ & $8 \mathrm{~F}$ \\
\hline Jahre et al. (2009) & $1 \mathrm{~B} 2 \mathrm{~B}$ & $3 \mathrm{~A} / 3 \mathrm{H}$ & $4 \mathrm{E}$ & $5 \mathrm{~A} / 5 \mathrm{~B} / 5 \mathrm{C}$ & $6 \mathrm{E}$ & $7 \mathrm{~B}$ & $8 \mathrm{D}$ \\
\hline Kovács and Spens (2009) & $1 \mathrm{~B} 2 \mathrm{~B}$ & $3 \mathrm{~A} / 3 \mathrm{G} / 3 \mathrm{~J}$ & $4 \mathrm{~A} / 4 \mathrm{~B} / 4 \mathrm{C} / 4 \mathrm{D}$ & $5 \mathrm{~A} / 5 \mathrm{~B} / 5 \mathrm{C}$ & $6 \mathrm{E}$ & 7B & $8 \mathrm{D}$ \\
\hline Kovács and Tatham (2009) & $1 \mathrm{D} 2 \mathrm{~B}$ & $3 \mathrm{C}$ & $4 \mathrm{E}$ & $5 \mathrm{D}$ & $6 \mathrm{E}$ & $7 \mathrm{~B}$ & $8 \mathrm{E}$ \\
\hline der Laan et al. (2009) & $1 \mathrm{~A} 2 \mathrm{~A}$ & $3 \mathrm{~A} / 3 \mathrm{G}$ & $4 \mathrm{E}$ & $5 \mathrm{~A}$ & $6 \mathrm{~A}$ & $7 \mathrm{~B}$ & $8 \mathrm{~F}$ \\
\hline der Laan et al. (2009) & $1 \mathrm{~A} 2 \mathrm{~B}$ & $3 \mathrm{~A} / 3 \mathrm{G}$ & $4 \mathrm{E}$ & $5 \mathrm{~A}$ & $6 \mathrm{~A}$ & $7 \mathrm{~B}$ & $8 \mathrm{~F}$ \\
\hline Trestrail et al. (2009) & $1 \mathrm{~A} 2 \mathrm{~B}$ & $3 \mathrm{~B} / 3 \mathrm{D}$ & $4 \mathrm{E}$ & $5 \mathrm{~A}$ & $6 \mathrm{~B}$ & $7 \mathrm{~A}$ & $8 \mathrm{~A}$ \\
\hline Chandes and Paché (2010a) & $1 \mathrm{~B} 2 \mathrm{C}$ & $3 \mathrm{G}$ & $4 \mathrm{D}$ & $5 \mathrm{C}$ & $6 \mathrm{~B}$ & $7 \mathrm{~A} / 7 \mathrm{~B}$ & $8 \mathrm{~A}$ \\
\hline Chandes and Paché (2010a) & $1 \mathrm{~B} 2 \mathrm{C}$ & $3 \mathrm{~J}$ & $4 \mathrm{D}$ & $5 \mathrm{~B} / 5 \mathrm{C}$ & $6 \mathrm{E}$ & $7 \mathrm{~B}$ & $8 \mathrm{~A}$ \\
\hline Chandes and Pache (2010b) & 1B $2 \mathrm{~B}$ & $3 \mathrm{G}$ & $4 \mathrm{D}$ & $5 \mathrm{~B}$ & $6 \mathrm{~A} / 6 \mathrm{~B} / 6 \mathrm{D}$ & $7 \mathrm{~A}$ & $8 \mathrm{~A}$ \\
\hline Ertem et al. (2010) & $1 \mathrm{D} 2 \mathrm{~A}$ & $3 \mathrm{~F}$ & $4 \mathrm{E}$ & $5 \mathrm{D}$ & $6 \mathrm{E}$ & $7 \mathrm{~A}$ & $8 \mathrm{~F}$ \\
\hline Jahre and Jensen (2010) & $1 \mathrm{D} 2 \mathrm{~B}$ & $3 \mathrm{~A} / 3 \mathrm{I}$ & $4 \mathrm{E}$ & $5 \mathrm{D}$ & $6 \mathrm{E}$ & $7 \mathrm{~B}$ & $8 \mathrm{~F}$ \\
\hline Tatham and Kovács (2010) & $1 \mathrm{D} 2 \mathrm{~B}$ & $3 \mathrm{C}$ & $4 \mathrm{D}$ & $5 \mathrm{~B}$ & $6 \mathrm{E}$ & $7 \mathrm{~B}$ & $8 \mathrm{~F}$ \\
\hline Kovács and Spens (2011a) & $1 \mathrm{D} 2 \mathrm{~B}$ & $3 \mathrm{C}$ & $4 \mathrm{E}$ & $5 \mathrm{D}$ & $6 \mathrm{E}$ & $7 \mathrm{~B}$ & $8 \mathrm{~F}$ \\
\hline Kovács and Spens (2011b) & $1 \mathrm{D} 2 \mathrm{C}$ & $3 \mathrm{C}$ & $4 \mathrm{E}$ & $5 \mathrm{D}$ & $6 \mathrm{E}$ & $7 \mathrm{~B}$ & $8 \mathrm{~F}$ \\
\hline Kovács and Spens (2011c) & $1 \mathrm{D} 2 \mathrm{C}$ & $3 \mathrm{~A}$ & $4 \mathrm{E}$ & $5 \mathrm{D}$ & $6 \mathrm{E}$ & $7 \mathrm{~B}$ & $8 \mathrm{~F}$ \\
\hline McLachlin and Larson (2011) & $1 \mathrm{~A} 2 \mathrm{~A}$ & $3 \mathrm{~A} / 3 \mathrm{I}$ & $4 \mathrm{E}$ & $5 \mathrm{D}$ & $6 \mathrm{E}$ & $7 \mathrm{~A}$ & $8 \mathrm{~F}$ \\
\hline Overstreet et al. (2011) & $1 \mathrm{D} 2 \mathrm{~B}$ & $3 \mathrm{C}$ & $4 \mathrm{E}$ & $5 \mathrm{D}$ & $6 \mathrm{E}$ & $7 \mathrm{~A}$ & $8 \mathrm{~F}$ \\
\hline Tatham and Houghton (2011) & $1 \mathrm{D} 2 \mathrm{~B}$ & $3 \mathrm{C}$ & $4 \mathrm{E}$ & $5 \mathrm{D}$ & $6 \mathrm{E}$ & $7 \mathrm{E}$ & $8 \mathrm{~F}$ \\
\hline Tatham and Spens (2011) & $1 \mathrm{D} 2 \mathrm{~B}$ & $3 \mathrm{C}$ & $4 \mathrm{E}$ & $5 \mathrm{~A}$ & $6 \mathrm{E}$ & $7 \mathrm{E}$ & $8 \mathrm{~F}$ \\
\hline Yang et al. (2011) & $1 \mathrm{D} 2 \mathrm{~B}$ & $3 \mathrm{~J}$ & $4 \mathrm{E}$ & $5 \mathrm{D}$ & $6 \mathrm{E}$ & $7 \mathrm{~B}$ & $8 \mathrm{~F}$ \\
\hline Cozzolino et al. (2012) & $1 \mathrm{~B} 2 \mathrm{~B}$ & $3 \mathrm{~A} / 3 \mathrm{G}$ & $4 \mathrm{~A}$ & $5 \mathrm{~A}$ & $6 \mathrm{~A}$ & $7 \mathrm{~B}$ & $8 \mathrm{D}$ \\
\hline Heaslip et al. (2012) & $1 \mathrm{D} 2 \mathrm{~B}$ & $3 \mathrm{C}$ & $4 \mathrm{E}$ & $5 \mathrm{~A}$ & $6 \mathrm{E}$ & $7 \mathrm{~B}$ & $8 \mathrm{~F}$ \\
\hline John et al. (2012) & $1 \mathrm{D} 2 \mathrm{C}$ & $3 \mathrm{C}$ & $4 \mathrm{~A} / 4 \mathrm{~B} / 4 \mathrm{C} / 4 \mathrm{D}$ & $5 \mathrm{~A} / 5 \mathrm{~B} / 5 \mathrm{C}$ & $6 \mathrm{E}$ & $7 \mathrm{C}$ & $8 \mathrm{~F}$ \\
\hline Kunz and Reiner (2012) & $1 \mathrm{D} 2 \mathrm{~B}$ & $3 \mathrm{C}$ & $4 \mathrm{E}$ & $5 \mathrm{D}$ & $6 \mathrm{E}$ & $7 \mathrm{~B}$ & $8 \mathrm{~F}$ \\
\hline Sheller (2012) & $1 \mathrm{~B} 2 \mathrm{~B}$ & $3 \mathrm{~A} / 3 \mathrm{G}$ & $4 \mathrm{D}$ & $5 \mathrm{C}$ & $6 \mathrm{E}$ & $7 \mathrm{~A}$ & $8 \mathrm{~A}$ \\
\hline Tatham (2012) & $1 \mathrm{D} 2 \mathrm{C}$ & $3 \mathrm{~K}$ & $4 \mathrm{E}$ & $5 \mathrm{D}$ & $6 \mathrm{E}$ & $7 \mathrm{E}$ & $8 \mathrm{~F}$ \\
\hline Holgun-Veras et al. (2012b) & $1 \mathrm{D} 2 \mathrm{~B}$ & $3 \mathrm{C}$ & $4 \mathrm{D}$ & $5 \mathrm{~B}$ & $6 \mathrm{E}$ & $7 \mathrm{~A}$ & $8 \mathrm{~F}$ \\
\hline Holgun-Veras et al. (2012a) & $1 \mathrm{~B} 2 \mathrm{~B}$ & $3 \mathrm{~A} / 3 \mathrm{G}$ & $4 \mathrm{D}$ & $5 \mathrm{C}$ & $6 \mathrm{~A}$ & $7 \mathrm{~A}$ & $8 \mathrm{~A}$ \\
\hline Wassenhove and Martinez (2012) & $1 \mathrm{C} 2 \mathrm{C}$ & $3 \mathrm{~B} / 3 \mathrm{I} / 3 \mathrm{~F}$ & $4 \mathrm{E}$ & $5 \mathrm{D}$ & $6 \mathrm{E}$ & $7 \mathrm{~B}$ & $8 \mathrm{~B} / 8 \mathrm{D}$ \\
\hline Bölsche et al. (2013) & $1 \mathrm{D} 2 \mathrm{~B}$ & $3 \mathrm{~A} / 3 \mathrm{E}$ & $4 \mathrm{E}$ & $5 \mathrm{~B}$ & $6 \mathrm{E}$ & $7 \mathrm{~B}$ & $8 \mathrm{~F}$ \\
\hline Goffnett et al. (2013) & $1 \mathrm{~A} 2 \mathrm{C}$ & $3 \mathrm{G}$ & $4 \mathrm{E}$ & $5 \mathrm{D}$ & $6 \mathrm{E}$ & $7 \mathrm{~A}$ & $8 \mathrm{~F}$ \\
\hline Heaslip (2013) & $1 \mathrm{D} 2 \mathrm{C}$ & $3 \mathrm{C}$ & $4 \mathrm{E}$ & $5 \mathrm{D}$ & $6 \mathrm{E}$ & $7 \mathrm{~B}$ & $8 \mathrm{E}$ \\
\hline Lu et al. (2013) & $1 \mathrm{~B} 2 \mathrm{~B}$ & $3 \mathrm{~A} / 3 \mathrm{G}$ & $4 \mathrm{~A}$ & $5 \mathrm{~B}$ & $6 \mathrm{D}$ & $7 \mathrm{C}$ & $8 \mathrm{D}$ \\
\hline Pedraza-Martinez et al. (2013) & $1 \mathrm{D} 2 \mathrm{~B}$ & $3 \mathrm{~A}$ & $4 \mathrm{E}$ & $5 \mathrm{D}$ & $6 \mathrm{C}$ & $7 \mathrm{~A}$ & $8 \mathrm{~F}$ \\
\hline Pateman et al. (2013) & $1 \mathrm{D} 2 \mathrm{~A}$ & $3 \mathrm{~A}$ & $4 \mathrm{~B} / 4 \mathrm{D}$ & $5 \mathrm{D}$ & $6 \mathrm{E}$ & $7 \mathrm{E}$ & $8 \mathrm{~F}$ \\
\hline Sheppard et al. (2013) & $1 \mathrm{~B} 2 \mathrm{~B}$ & $3 \mathrm{~A} / 3 \mathrm{I}$ & $4 \mathrm{D}$ & $5 \mathrm{~B}$ & $6 \mathrm{E}$ & $7 \mathrm{E}$ & $8 \mathrm{C}$ \\
\hline Holgun-Veras et al. (2013) & $1 \mathrm{D} 2 \mathrm{~B}$ & $3 \mathrm{D}$ & $4 \mathrm{D}$ & $5 \mathrm{~B}$ & $6 \mathrm{E}$ & $7 \mathrm{~A}$ & $8 \mathrm{~F}$ \\
\hline Abidi et al. (2014) & $1 \mathrm{D} 2 \mathrm{~A}$ & $3 \mathrm{C}$ & $4 \mathrm{E}$ & $5 \mathrm{~A} / 5 \mathrm{~B} / 5 \mathrm{C}$ & $6 \mathrm{E}$ & $7 \mathrm{~B}$ & $8 \mathrm{~F}$ \\
\hline
\end{tabular}


Table 2 continued

\begin{tabular}{|c|c|c|c|c|c|c|c|}
\hline Studies & Categor & & & & & & \\
\hline Bhattacharya et al. (2014) & $1 \mathrm{D} 2 \mathrm{C}$ & $3 \mathrm{D}$ & $4 \mathrm{E}$ & $5 \mathrm{~B}$ & $6 \mathrm{E}$ & $7 \mathrm{C}$ & $8 \mathrm{~F}$ \\
\hline Diaz-Delgado and Gaytan Iniestra (2014) & 1B $2 \mathrm{~B}$ & $3 \mathrm{G}$ & $4 \mathrm{D}$ & $5 \mathrm{C}$ & $6 \mathrm{~B}$ & $7 \mathrm{~A}$ & $8 \mathrm{~A}$ \\
\hline Dubey et al. (2014) & $1 \mathrm{~B} 2 \mathrm{~A}$ & $3 \mathrm{~B} / 3 \mathrm{E}$ & $4 \mathrm{E}$ & $5 \mathrm{~A} / 5 \mathrm{C}$ & $6 \mathrm{E}$ & 7C & $8 \mathrm{C}$ \\
\hline Haavisto and Kovács (2014) & $1 \mathrm{D} 2 \mathrm{~B}$ & $3 \mathrm{~A} / 3 \mathrm{~J}$ & $4 \mathrm{E}$ & $5 \mathrm{D}$ & $6 \mathrm{~A} / 6 \mathrm{C}$ & 7B & $8 \mathrm{~F}$ \\
\hline Iakovou et al. (2014) & $1 \mathrm{D} 2 \mathrm{C}$ & $3 \mathrm{D}$ & $4 \mathrm{~A} / 4 \mathrm{C}$ & $5 \mathrm{~A} / 5 \mathrm{~B} / 5 \mathrm{C}$ & $6 \mathrm{E}$ & 7B & $8 \mathrm{~F}$ \\
\hline Leiras et al. (2014) & $1 \mathrm{D} 2 \mathrm{~B}$ & $3 \mathrm{C}$ & $4 \mathrm{E}$ & $5 \mathrm{D}$ & $6 \mathrm{E}$ & $7 \mathrm{~A}$ & $8 \mathrm{E}$ \\
\hline Liberatore et al. (2014) & $1 \mathrm{D} 2 \mathrm{~B}$ & $3 \mathrm{D}$ & $4 \mathrm{D}$ & $5 \mathrm{~B}$ & $6 \mathrm{E}$ & 7B & $8 \mathrm{D}$ \\
\hline Lima et al. (2014) & 1B 2B & $3 \mathrm{~B} / 3 \mathrm{D} / 3 \mathrm{G}$ & $4 \mathrm{D}$ & $5 \mathrm{~B}$ & $6 \mathrm{E}$ & $7 \mathrm{~A}$ & $8 \mathrm{~A}$ \\
\hline Matopoulos et al. (2014) & $1 \mathrm{~B} 2 \mathrm{~A}$ & $3 \mathrm{~A} / 3 \mathrm{~J}$ & $4 \mathrm{~A}$ & $5 \mathrm{C}$ & $6 \mathrm{D}$ & $7 \mathrm{~B}$ & $8 \mathrm{~B}$ \\
\hline Mulyono and Ishida (2014) & 1B $2 \mathrm{~B}$ & $3 \mathrm{D}$ & $4 \mathrm{D}$ & $5 \mathrm{~B}$ & $6 \mathrm{~B} / 6 \mathrm{D}$ & $7 \mathrm{C}$ & $8 \mathrm{C}$ \\
\hline Özpolat et al. (2014) & $1 \mathrm{~A} 2 \mathrm{~B}$ & $3 \mathrm{~A} / 3 \mathrm{~J}$ & $4 \mathrm{E}$ & $5 \mathrm{D}$ & $6 \mathrm{E}$ & 7C & $8 \mathrm{~F}$ \\
\hline Şahin et al. (2014) & 1B 2B & $3 \mathrm{~B} / 3 \mathrm{E}$ & $4 \mathrm{D}$ & $5 \mathrm{~B}$ & $6 \mathrm{~B}$ & 7B & $8 \mathrm{~B}$ \\
\hline Schiffling and Piecyk (2014) & $1 \mathrm{D} 2 \mathrm{~A}$ & $3 \mathrm{C}$ & $4 \mathrm{E}$ & $5 \mathrm{D}$ & $6 \mathrm{E}$ & 7B & $8 \mathrm{~F}$ \\
\hline Holgun-Veras et al. (2014) & $1 \mathrm{~A} 2 \mathrm{~B}$ & $3 I$ & $4 \mathrm{D}$ & $5 \mathrm{D}$ & $6 \mathrm{~A}$ & $7 \mathrm{~A}$ & $8 \mathrm{C}$ \\
\hline Ye and Liu (2014) & $1 \mathrm{~B} 2 \mathrm{~B}$ & $3 \mathrm{~B} / 3 \mathrm{D} / 3 \mathrm{G}$ & $4 \mathrm{D}$ & $5 \mathrm{~B}$ & $6 \mathrm{E}$ & $7 \mathrm{C}$ & $8 \mathrm{C}$ \\
\hline Abidi et al. (2015) & $1 \mathrm{D} 2 \mathrm{C}$ & 3B & $4 \mathrm{E}$ & $5 \mathrm{D}$ & $6 \mathrm{E}$ & 7B & $8 \mathrm{~F}$ \\
\hline Ahmadi et al. (2015) & $1 \mathrm{~A} 2 \mathrm{~B}$ & $3 \mathrm{~B} / 3 \mathrm{D}$ & $4 \mathrm{D}$ & $5 \mathrm{~B} / 5 \mathrm{C}$ & $6 \mathrm{E}$ & $7 \mathrm{C}$ & $8 \mathrm{~A}$ \\
\hline Dubey and Gunasekaran (2015) & $1 \mathrm{~B} 2 \mathrm{C}$ & $3 \mathrm{~K}$ & $4 \mathrm{E}$ & $5 \mathrm{D}$ & $6 \mathrm{E}$ & 7C & $8 \mathrm{C}$ \\
\hline Dubey et al. (2015) & $1 \mathrm{~B} 2 \mathrm{C}$ & $3 \mathrm{~B} / 3 \mathrm{E}$ & $4 \mathrm{E}$ & $5 \mathrm{D}$ & $6 \mathrm{E}$ & $7 \mathrm{C}$ & $8 \mathrm{C}$ \\
\hline Gralla et al. (2015) & $1 \mathrm{D} 2 \mathrm{~B}$ & $3 \mathrm{~A} / 3 \mathrm{E} / 3 \mathrm{G}$ & $4 \mathrm{D}$ & $5 \mathrm{~B}$ & $6 \mathrm{~A}$ & $7 \mathrm{~A}$ & $8 \mathrm{~A}$ \\
\hline Haavisto and Goentzel (2015) & $1 \mathrm{D} 2 \mathrm{~A}$ & & $4 \mathrm{E}$ & $5 \mathrm{~A}$ & $6 \mathrm{E}$ & $7 \mathrm{~B}$ & $8 \mathrm{~F}$ \\
\hline D'Haene et al. (2015) & $1 \mathrm{~A} 2 \mathrm{~A}$ & $3 \mathrm{~A} / 3 \mathrm{I}$ & $4 \mathrm{E}$ & $5 \mathrm{D}$ & $6 \mathrm{D} / 6 \mathrm{C}$ & $7 \mathrm{~B}$ & $8 \mathrm{~F}$ \\
\hline Heaslip (2015) & $1 \mathrm{D} 2 \mathrm{C}$ & $3 \mathrm{C}$ & $4 \mathrm{E}$ & $5 \mathrm{D}$ & $6 \mathrm{E}$ & $7 \mathrm{E}$ & $8 \mathrm{~F}$ \\
\hline L'Hermitte et al. (2015) & $1 \mathrm{D} 2 \mathrm{~A}$ & $3 \mathrm{~A}$ & $4 \mathrm{E}$ & $5 \mathrm{D}$ & $6 \mathrm{E}$ & $7 \mathrm{E}$ & $8 \mathrm{~F}$ \\
\hline Jahre and Fabbe-Costes (2015) & $1 \mathrm{~A} 2 \mathrm{~A}$ & $3 \mathrm{G} / 3 \mathrm{I}$ & $4 \mathrm{E}$ & $5 \mathrm{~B}$ & $6 \mathrm{~B}$ & $7 \mathrm{~B}$ & $8 \mathrm{~F}$ \\
\hline Kabra and Ramesh (2015b) & $1 \mathrm{~B} 2 \mathrm{~A}$ & $3 \mathrm{~K}$ & $4 \mathrm{D}$ & $5 \mathrm{~A} / 5 \mathrm{~B}$ & $6 \mathrm{E}$ & 7C & $8 \mathrm{C}$ \\
\hline Kabra et al. (2015) & $1 \mathrm{~B} 2 \mathrm{C}$ & $3 \mathrm{~K}$ & $4 \mathrm{D}$ & $5 \mathrm{~B}$ & $6 \mathrm{D}$ & $7 \mathrm{C}$ & $8 \mathrm{C}$ \\
\hline Kabra and Ramesh (2015a) & $1 \mathrm{~B} 2 \mathrm{~A}$ & & $4 \mathrm{E}$ & $5 \mathrm{~A}$ & $6 \mathrm{E}$ & $7 \mathrm{C}$ & $8 \mathrm{C}$ \\
\hline Kunz and Gold (2017) & $1 \mathrm{~A} 2 \mathrm{~A}$ & $3 \mathrm{H}$ & $4 \mathrm{E}$ & $5 \mathrm{~A}$ & $6 \mathrm{E}$ & $7 \mathrm{~A}$ & $8 \mathrm{~B}$ \\
\hline Santarelli et al. (2015) & $1 \mathrm{C} 2 \mathrm{C}$ & & $4 \mathrm{D}$ & $5 \mathrm{~B} / 5 \mathrm{C}$ & $6 \mathrm{~B} / 6 \mathrm{C} / 6 \mathrm{D}$ & 7B & $8 \mathrm{~F}$ \\
\hline Tabaklar et al. (2015) & $1 \mathrm{D} 2 \mathrm{~A}$ & $3 \mathrm{C}$ & $4 \mathrm{E}$ & $5 \mathrm{D}$ & $6 \mathrm{E}$ & 7B & $8 \mathrm{~F}$ \\
\hline Tatham and Spens (2015) & $1 \mathrm{D} 2 \mathrm{~B}$ & $3 \mathrm{C}$ & $4 \mathrm{E}$ & $5 \mathrm{D}$ & $6 \mathrm{D}$ & $7 \mathrm{E}$ & $8 \mathrm{~F}$ \\
\hline Vega and Roussat (2015) & $1 \mathrm{D} 2 \mathrm{~B}$ & $3 \mathrm{~A} / 3 \mathrm{~J}$ & $4 \mathrm{E}$ & $5 \mathrm{D}$ & $6 \mathrm{E}$ & $7 \mathrm{~B}$ & $8 \mathrm{~F}$ \\
\hline Yadav and Barve (2015) & $1 \mathrm{D} 2 \mathrm{C}$ & $3 \mathrm{~A}$ & $4 \mathrm{E}$ & $5 \mathrm{D}$ & $6 \mathrm{E}$ & $7 \mathrm{C}$ & $8 \mathrm{~F}$ \\
\hline Connelly et al. (2016) & $1 \mathrm{~B} 2 \mathrm{~A}$ & $3 \mathrm{G}$ & $4 \mathrm{E}$ & $5 \mathrm{~A}$ & $6 \mathrm{~B}$ & $7 \mathrm{~A}$ & $8 \mathrm{~A}$ \\
\hline Rodrguez-Espndola et al. (2016) & 1B $2 \mathrm{~B}$ & $3 \mathrm{~B} / 3 \mathrm{H}$ & $4 \mathrm{D}$ & $5 \mathrm{~A}$ & $6 \mathrm{~B}$ & $7 \mathrm{~A}$ & $8 \mathrm{~A}$ \\
\hline Habib et al. (2016) & $1 \mathrm{D} 2 \mathrm{~A}$ & $3 \mathrm{C}$ & $4 \mathrm{E}$ & $5 \mathrm{D}$ & $6 \mathrm{E}$ & $7 \mathrm{E}$ & $8 \mathrm{~F}$ \\
\hline L'Hermitte et al. (2016) & $1 \mathrm{D} 2 \mathrm{~B}$ & $3 \mathrm{G}$ & $4 \mathrm{E}$ & $5 \mathrm{~A}$ & $6 \mathrm{~A}$ & $7 \mathrm{E}$ & $8 \mathrm{~F}$ \\
\hline Jensen and Hertz (2016) & 1B 2B & $3 \mathrm{~A} / 3 \mathrm{G} / 3 \mathrm{I}$ & $4 \mathrm{~A}$ & $5 \mathrm{~B} / 5 \mathrm{C}$ & $6 \mathrm{~A} / 6 \mathrm{D}$ & $7 \mathrm{~B}$ & $8 \mathrm{D}$ \\
\hline Ozkapici et al. (2016) & 1B 2B & $3 \mathrm{D}$ & $4 \mathrm{D}$ & $5 \mathrm{~B}$ & $6 \mathrm{E}$ & $7 \mathrm{~B} / 7 \mathrm{C}$ & $8 \mathrm{~B} / 8 \mathrm{C}$ \\
\hline Prasad et al. (2016) & $1 \mathrm{~B} 2 \mathrm{~A}$ & $3 \mathrm{~F}$ & $4 \mathrm{E}$ & $5 \mathrm{~A}$ & $6 \mathrm{D}$ & $7 \mathrm{~A}$ & $8 \mathrm{C}$ \\
\hline Tofighi et al. (2016) & 1B $2 \mathrm{~B}$ & $3 \mathrm{~B} / 3 \mathrm{H}$ & $4 \mathrm{D}$ & $5 \mathrm{~A}$ & $6 \mathrm{~B}$ & $7 \mathrm{C}$ & $8 \mathrm{C}$ \\
\hline
\end{tabular}


Table 2 continued

\begin{tabular}{|c|c|c|c|c|c|c|c|c|}
\hline \multirow{2}{*}{$\begin{array}{l}\text { Studies } \\
\text { Vaillancourt (2016a) }\end{array}$} & \multicolumn{8}{|c|}{ Categories } \\
\hline & $1 \mathrm{D}$ & $2 \mathrm{~B}$ & $3 \mathrm{H} / 3 \mathrm{I}$ & $4 \mathrm{E}$ & $5 B$ & $6 \mathrm{~A}$ & $7 \mathrm{~B}$ & $8 \mathrm{~F}$ \\
\hline Vaillancourt (2016b) & $1 \mathrm{D}$ & $2 \mathrm{~B}$ & $3 \mathrm{~J}$ & $4 \mathrm{E}$ & $5 \mathrm{D}$ & $6 \mathrm{E}$ & $7 \mathrm{~B}$ & $8 \mathrm{~F}$ \\
\hline Yadav and Barve (2016) & $1 \mathrm{~B}$ & $2 \mathrm{~A}$ & $3 \mathrm{~B} / 3 \mathrm{G} / 3 \mathrm{~F}$ & $4 \mathrm{D}$ & $5 \mathrm{~B} / 5 \mathrm{C}$ & $6 \mathrm{D}$ & $7 \mathrm{C}$ & $8 \mathrm{C}$ \\
\hline
\end{tabular}

caused by intentional or unintentional breaks in HSCs, and Kaur and Singh (2016), in turn, have studied relationships between such resilient supply chains and sustainability outcomes.

In a disaster situation, logistics can be considered a critical activity that differentiates between a successful and a failed relief operation (Cozzolino et al. 2012). Indeed, the impact of a disaster is mostly seen on human mortality and their livelihood perspective, but a huge loss to economies is also associated with such disasters too (see Yadav and Barve 2015). From this perspective, disaster management and relief aid require complex logistical activities, as the resources they need are rarely available at the location of the disaster. These logistical activities are generally referred to as HL (Kunz et al. 2014).

An important point raised by Oloruntoba et al. (2016) is the fact that HLSCM still lacks theoretical development, and they suggest using the theories of behavioral and organizational economic internationalization to further progress it. Coles et al. (2017) emphasize the gap between theory and practice in the area of disaster management, and to remedy such failure have conducted a review of the International Federation of Red Cross and Red Crescent Societies (IFRC) to do so.

\section{Results and discussion}

The purpose of this section is to understand the research results obtained from our classification of the articles described in Table 2. Our results are presented through use of the defined categories detailed in Table 1 in the following subsections of: economic context, focus, methods, disaster type, relief phase, organizational type, author region, article purpose and interesting research gaps. We begin with economic context, and then detail each of the subsections above in turn.

\subsection{Economic context}

Based on the articles that were classified in categories 1A, 1B, 1C and 1D shown in Fig. 1, most such studies did not analyse a specific region (52\%), and those which did investigate a region primarily analysed non-mature economies (33\%). According to The United Nations Office for Disaster Risk Reduction (UNISDR 2016), the main countries affected by disasters in terms of people killed between 1992 and 2012 were Haiti, Indonesia and Myanmar. Considering that a natural disaster, in particular, would occur again due to geographic conditions, a research gap in this topic is:

$G A P_{1}$ Which lessons would be learnt from non-mature economies in order to foresee, and be prepared for natural disasters?

\subsection{Focus}

Our second category identifies the main focus addressed in the previously considered articles in our literature review on HL and HSC. Here, relevant articles are classified in category 


\section{Category 1}

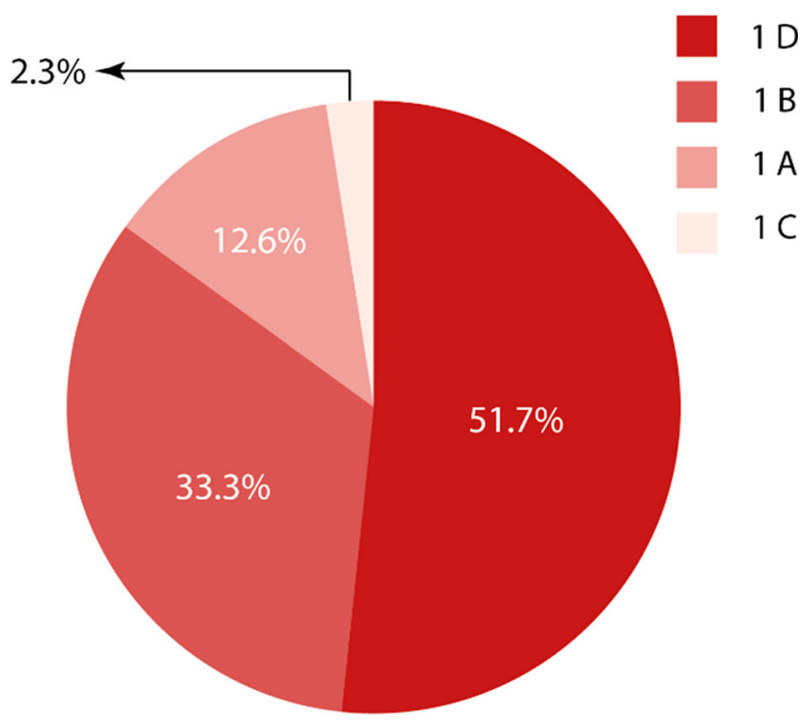

Fig. 1 Results obtained for Category 1

2A-SCM, 2B-Logistics, and in category, 2C-Both. As shown in Fig. 2, results indicate that most of these studies $(54.02 \%)$ focus mainly on logistics rather than considering the area of Supply Chain Management, or the interface between these two knowledge areas. One probable explanation for this result is that after a disaster, the transportation of injured people and moving supplies to devastated areas is one of the main tasks in this situation (Habib et al. 2016, p. 1). Implications arising are that researchers have studied more immediate responses than preparation and/or prevention events, and that preparation and prevention activities, which include a supply chain perspective, have been neglected by the relevant authorities due to the fact that there are few studies which analyse preventive actions to deal with such disasters. Supply chain perspective in a context of humanitarian operations means planning supply and demand issues considering volume and location of inventories in order to be available for an immediate response, alternative routes for transportation of goods and negotiation with suppliers to propose emergency plans (Holgun-Veras et al. 2012b). As such, we propose the following:

$G A P_{2}$ How are public and private sectors supply chains involved and organized to support the preparation and prevention of situations like natural and man-made disasters?

\subsection{Methods}

In this category, we identify the main research methods used in articles that address HLSCM. From our results presented in Table 2, most of the relevant studies are conceptual (26.44\%), as shown in Fig. 3.

However, when we analyse each category in isolation, in category $3 \mathrm{~A}$ articles dealing with the topic using qualitative methods are the majority (19.05\%), whereas articles that approach the topic quantitatively $(9.52 \%)$, or those that use mixed qualitative and quantitative methods together $(3.17 \%)$, are very few. Consequently, it seems plausible to argue that there is a need 
Fig. 2 Results obtained for Category 2

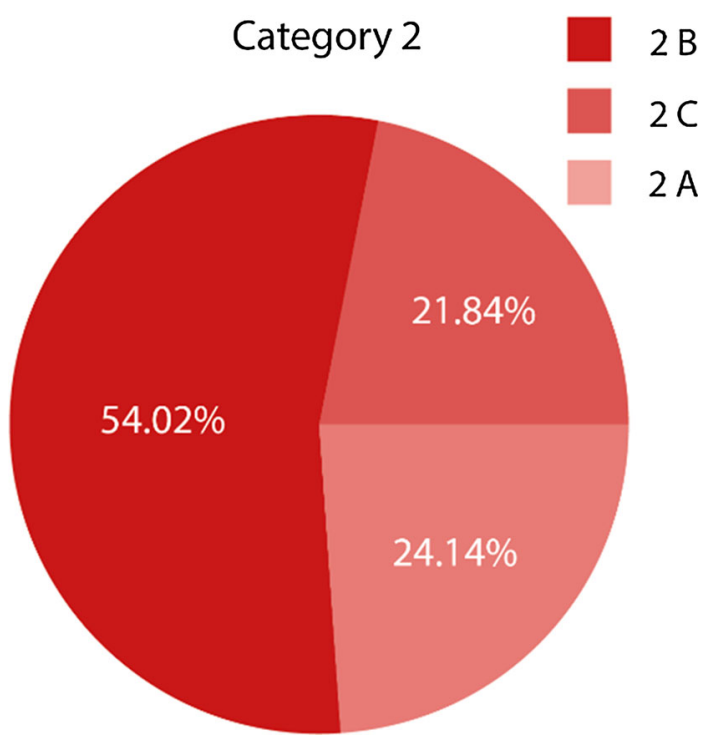

for researchers in the HLSCM area to use more quantitative methods or mixed methodologies in their work. In order to do so, it is necessary that data on different aspects of disasters are collected and made available on an open access basis, such as The International Disaster Database. This is because the more data or information regarding calamitous events are available, the greater the chances of developing a strategy of prevention or assistance to victims. Additionally, opening up databases on natural and man-made disasters could enable us to develop simulations of potential impacts, and to forecast potential disasters in order to develop efficient action plans regarding them. of actions. From the points above, we propose:

$G A P_{3}$ Which barriers exist to make quantitative studies feasible in the field of HLSCM? How is big data being used in the context of HLSCM?

\subsection{Type of disasters}

In order to deal with situations of disaster in a preventive way or by helping its victims, it is necessary to be aware of the two main types of disasters: natural or man-made, and also the speed of these events, i.e., if occasions are of a slow start (slow-onset) or a sudden start (sudden-onset). In this sense, as shown in Fig. 4, not even half of the studies $(43.16 \%)^{1}$ consider such type and speed aspects, and when they do, they are mostly directed at natural disasters of a sudden occurrence which, in turn, are explained by the need to operate efficiently to assist victims. This finding appears logical given the fact that the majority of the articles analysed are theoretical, so the distinction between different kinds of disasters is not always discussed in them. However, different kinds of disasters and their respective pace would require specific resources and capabilities in the operations of humanitarian logistics. Therefore, a research gap emerging is:

$\mathrm{GAP}_{4}$ Which resources and capabilities could be developed by organizations in order to deal with the different kinds, and pace of, disasters?

1 This value corresponds to the total number of papers (41) classified in the categories 4A, 4B, 4C and 4D divided by the total number (95) of classifications attributed to the articles analysed. 


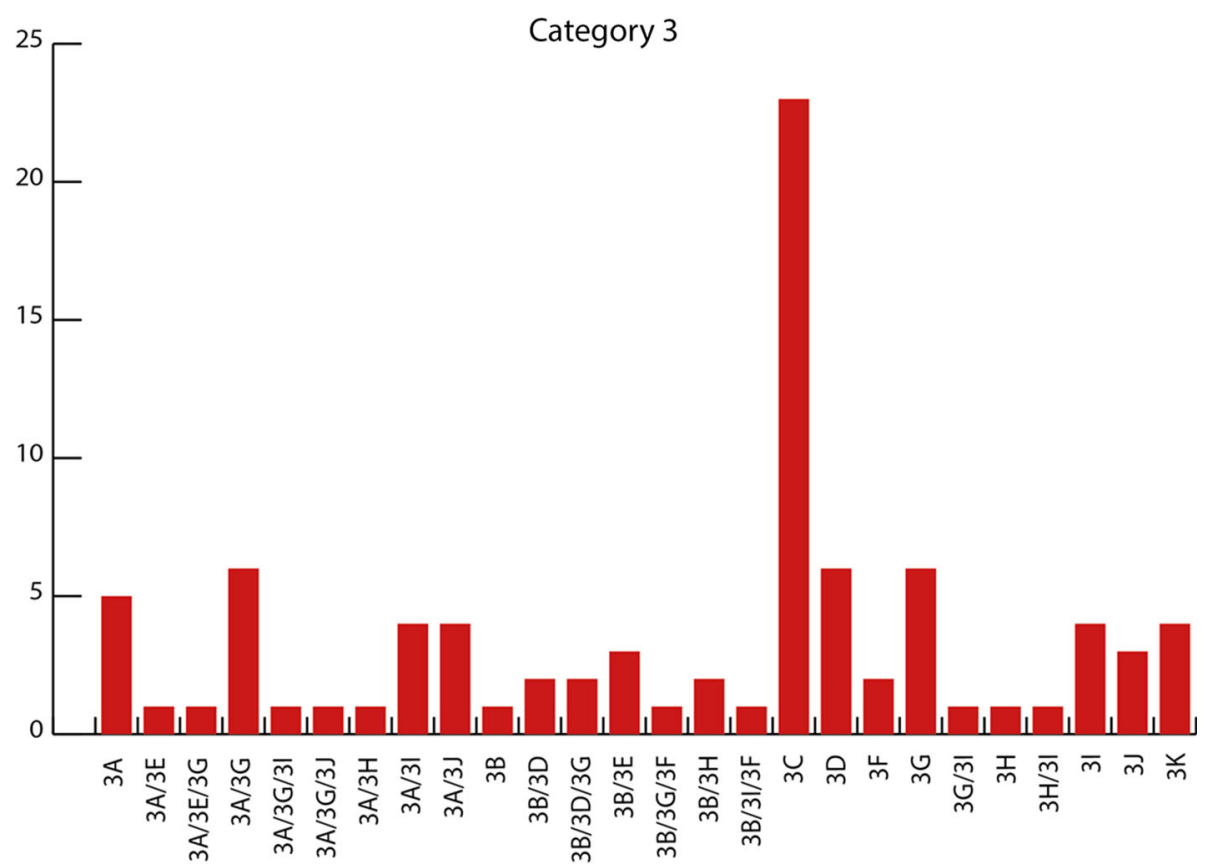

Fig. 3 Results obtained for Category 3

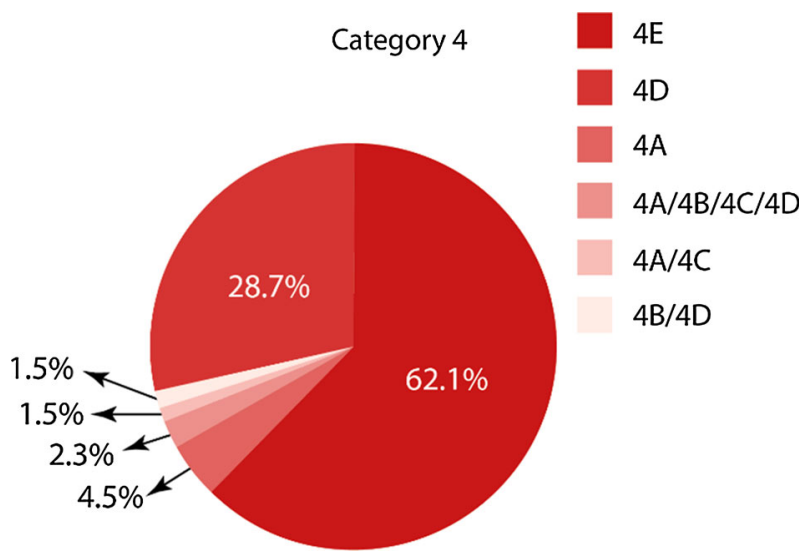

Fig. 4 Results obtained for Category 4

\subsection{Phases of the disaster relief}

In order to complement the finding of the Type of Disaster category, we identified how humanitarian logistics studies consider the Phases of Disaster Relief. Consequently, as shown in Fig. 5, most such works (41.38\%) did not observe or discuss these phases of disaster which, in turn, could be easily understood, since most of the articles on this subject are conceptual, as already explained in Sect. 5.3. However, regarding the articles that do consider this phase element, such works concentrate on the perspective of how the difficulties of immediate 


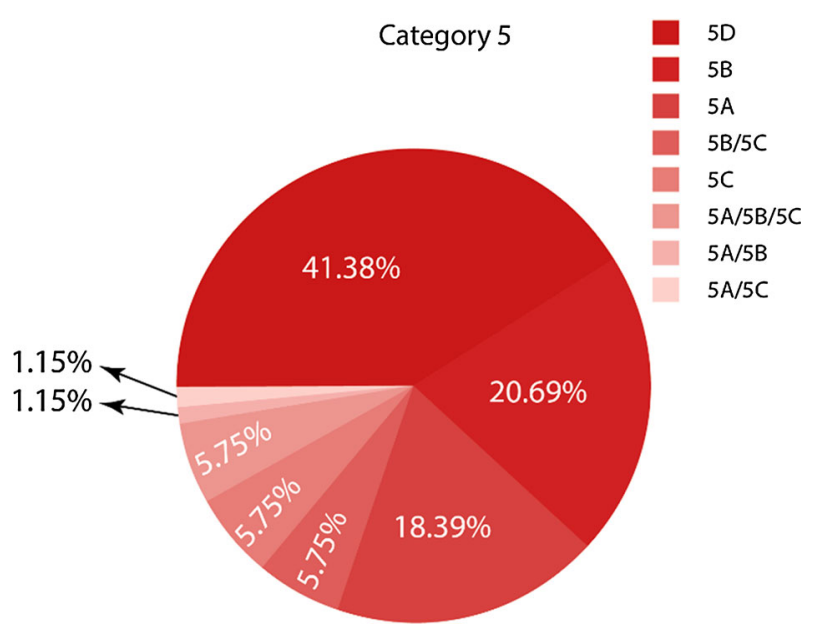

Fig. 5 Results obtained for Category 5

response (5B-20.69\%) can be overcome. This finding highlights that the main focus of such phase research is in how to deal with disasters rather than how to foresee or to be prepared for them. This result aligns to item 5.2, which may mean that either researchers have studied more emergency situations than preparation situations, or planning and preparation activities have been neglected by the relevant authorities. Therefore, it could be interesting to identify:

$G A P_{5}$ Which initiatives or plans of prevention to natural and man-made disasters are developed in countries devastated by these disasters? Which kind of approach has been adopted after facing such disasters?

\subsection{Type of humanitarian organization}

Category 6 identifies which organizations, national or global, are observed in the work of humanitarian logistics, since these organizations in various situations play a fundamental role in helping disaster victims. Based on results in Table 2 and Fig. 6, the relevant articles here mostly do not comment on such organizations (6E 65.52\%) or, when they do, present brief comments on supranational aid agencies $(6 \mathrm{~A}-10.34 \%)$ and governmental organizations $(6 \mathrm{~B}-9.20 \%)$. Looking at these notes, we ask:

$G A P_{6}$ How can humanitarian organizations coordinate with each other in order to support the preparation/prevention, immediate response, and reconstruction phases of disaster relief?

\subsection{Region of authorship and disasters}

Categories 7 and 8 sought to geographically locate the main areas or regions of authors on the theme of HLSCM in their studies and, consequently, the main continents considered in such studies. Most authors are from the United States (18.39\%) or from Europe, and specifically, from Finland (13.79\%). An explanation why most European work originates in Finland stems from the significant works of Prof. Gyöngyi Kovács and Prof. Karen M. Spens from the Hanken School of Economics in Finland. Regarding region of disasters, the majority of articles $(55.17 \%)$ do not allow this identification, since they are conceptual works, as indicated in Sect. 5.3. However, by observing the articles that explain this information, it was possible to identify that there is a great deal of interest from researchers in the Asian and 


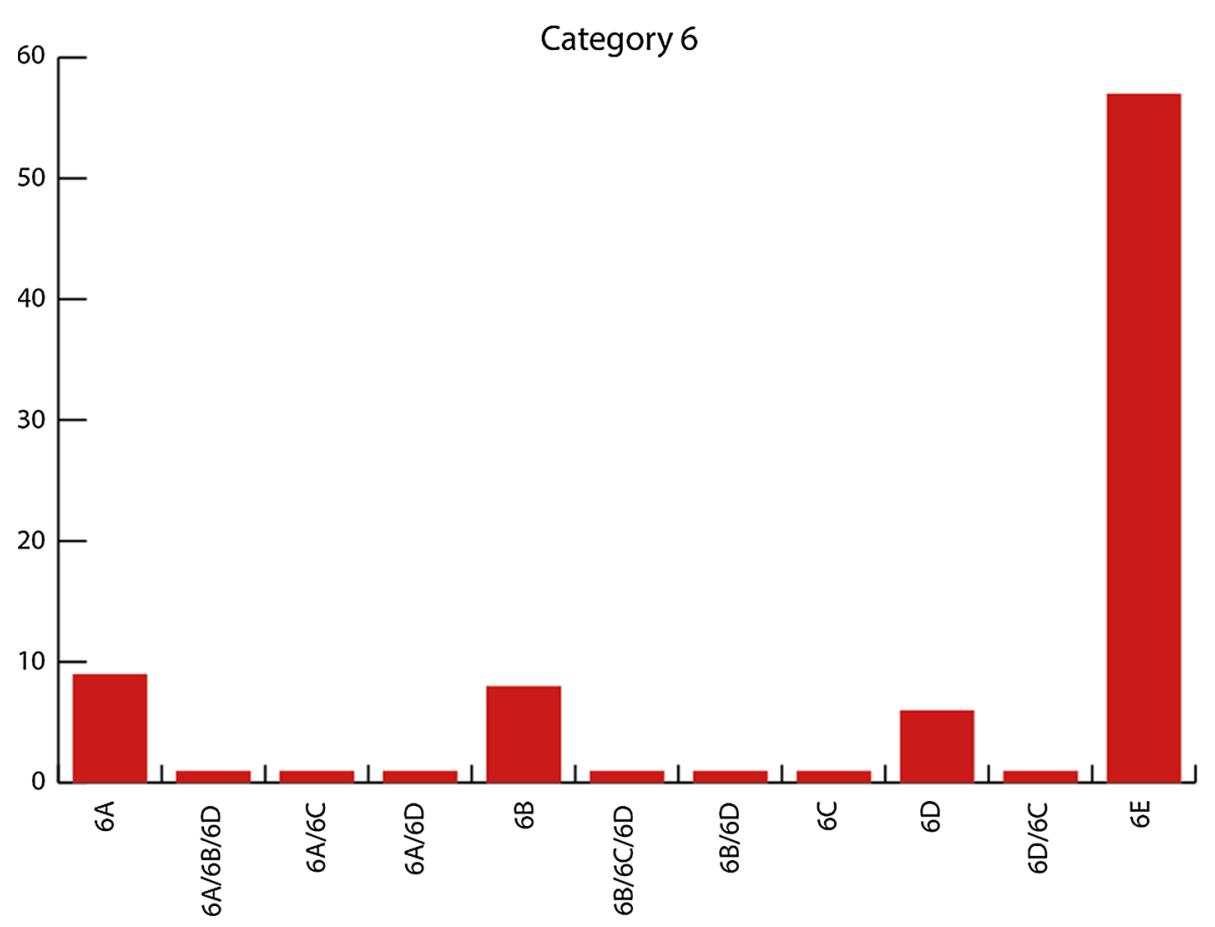

Fig. 6 Results obtained for Category 6

American continents. One possible explanation for this finding lies in the fact that in recent years' serious disasters have occurred in these localities.

\subsection{Purposes of articles analysed}

The articles selected were also analysed in terms of their objectives in order to synthesize the main streams of the HLSCM field, which are presented in Table 2 using content analysis, and a conceptual map was developed as shown in Fig. 7.

Five streams of research interest were identified in the field of HLSCM namely: logistical coordination, framework, traditional logistics and SCM versus HLSCM, performance measurement, and model, based on the number of topics found.

The logistics and SCM coordination stream is composed of understanding the lack of coordination between aid members, the necessity of developing relationships between the players involved in humanitarian operations and identification of challenges to promote coordination within humanitarian logistics activities. The framework suggests researchers investigating the topic of HLSCM through particular theoretical lenses, and consequently, proposing new future avenues of research interest. The traditional logistics and SCM vs HLSCM stream addresses which similarities exist between the activities and decisions of traditional ones, while the performance measurement stream discusses developing indicators in the HLSCM field. Lastly here, the model stream proposes mathematical models to plan routes of localisation of inventories, and to support decision making on resource allocation and recovery after disasters. 


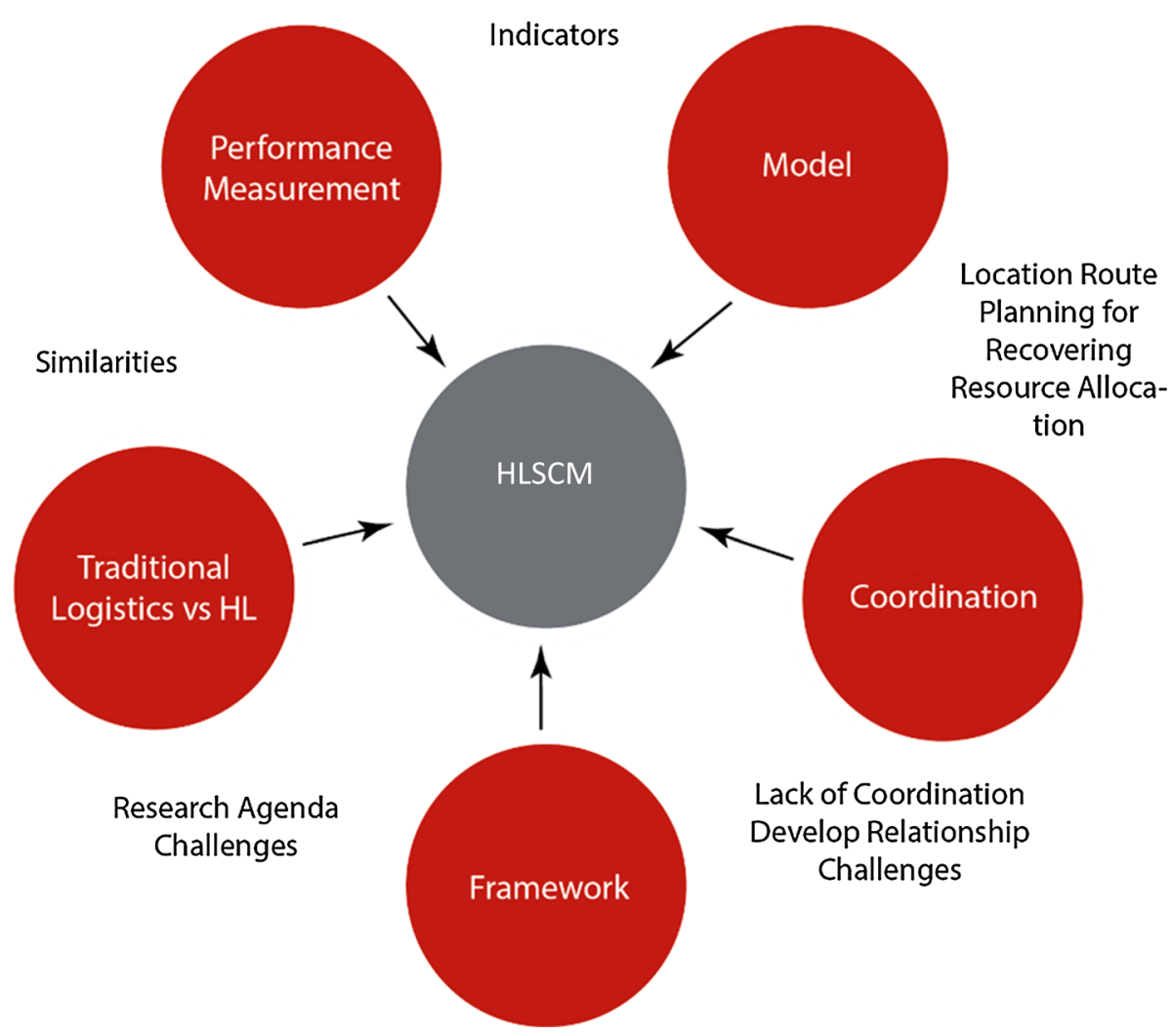

Fig. 7 Conceptual map

\subsection{Main gaps and fields of interest}

Based on our analysis, we identified six research gaps as well as the main fields of interest and trends for the HLSCM area. To summarize, the six research gaps identified during our literature review process are detailed below.

$G A P_{1}$ Which lessons would be learnt from non-mature economies in order to foresee, and be prepared for natural disasters?

$G A P_{2}$ How are public and private sectors supply chains involved and organized to support the preparation and prevention of situations like natural and man-made disasters?

$\mathrm{GAP}_{3}$ Which barriers exist to make quantitative studies feasible in the field? How is big data being used in the context?

$\mathrm{GAP}_{4}$ Which resources and capabilities could be developed by organizations in order to deal with the different kinds, and pace of, disasters?

$G A P_{5}$ Which initiatives or plans of prevention to natural and man-made disasters are developed in countries devastated by these disasters? Which kind of approach has been adopted after facing such disasters?

$G A P_{6}$ How can humanitarian organizations coordinate with each other in order to support the preparation/prevention, immediate response, and reconstruction phases of disaster relief? 
The main streams of research interest in the field are: coordination, frameworks, traditional versus HLSCM, performance measurement, and model.

Combining the information from our results and research gaps and streams, it could be argued that that more practitioner-focussed research is needed in the field of HLSCM, that preparation and prevention should be addressed either by academics and/or relevant authorities, and that supply chain context needs analysing in order to discuss coordination between aid members. Additionally, understanding the resources and capabilities of the players and agents involved of humanitarian operations seems pivotal to comprehending our proposed research gaps above.

\section{Conclusions}

This article synthesizes the research literature on HLSCM in order to organize it under a conceptual map and integrate existing ideas to create new ways of thinking and understanding this theme, using articles identified in Scopus and Web of Science using the terms "Humanitarian Supply Chain" or "Humanitarian Logistics". As a result of our initial search, 155 articles were refined using the filters "Article", "Review", "Article in Press", "Source Type Journal" and "English Language", which produced 87 articles available for full analysis and review.

The main results of our analysis are that the majority of our reviewed articles were theoretical, and as a consequence, few of them discussed issues related to localisation of disaster, type of disaster, phase of disaster relief, and type of humanitarian organization. Their focus was mainly on logistics.

This article contributes to the literature of the HLSCM field by proving a synthesis of this theme and highlighting new perspectives on how it has been addressed, along with potential development areas to further guide future research. The limitations of this article relate to the cognitive process of analysing the identified articles herein, and the filters selected to choose the articles reviewed, which we discussed.

Nonetheless, based on our findings we have proposed six new research gaps and developed an original conceptual map which charts five streams on how to further integrate the humanitarian logistics and supply chain management field, which both represent a new way to further understand this theme.

Further research is specifically needed to apply the concepts of HLSCM in different contexts. Here, wider geographical perspectives could empirically test the global validity of theories used in HLSCM research and understand context dependency in HLSCM. A requirement for further empirical and theoretical work exists regarding international humanitarian operations, as well as not-for-profit organizations.

Open Access This article is distributed under the terms of the Creative Commons Attribution 4.0 International License (http://creativecommons.org/licenses/by/4.0/), which permits unrestricted use, distribution, and reproduction in any medium, provided you give appropriate credit to the original author(s) and the source, provide a link to the Creative Commons license, and indicate if changes were made.

\section{References}

Abidi, H., Leeuw, S., \& Klumpp, M. (2014). Humanitarian supply chain performance management: A systematic literature review. Supply Chain Management: An International Journal, 19(5/6), 592-608. 
Abidi, H., Leeuw, S., \& Klumpp, M. (2015). The value of fourth-party logistics services in the humanitarian supply chain. Journal of Humanitarian Logistics and Supply Chain Management, 5(1), 35-60.

Ahmadi, M., Seifi, A., \& Tootooni, B. (2015). A humanitarian logistics model for disaster relief operation considering network failure and standard relief time: A case study on San Francisco district. Transportation Research Part E: Logistics and Transportation Review, 75(1), 145-163.

Akhtar, P., Marr, N. E., \& Garnevska, E. V. (2012). Coordination in humanitarian relief chains: Chain coordinators. Journal of Humanitarian Logistics and Supply Chain Management, 2(1), 85-103.

Anparasan, A., \& Lejeune, M. (2017). Resource deployment and donation allocation for epidemic outbreaks. Annals of Operations Research. doi:10.1007/s10479-016-2392-0, in press.

Apta, A. (2009). Humanitarian logistics: A new field of research and action. Foundations and Trends ${ }^{\circledR}$ in Technology, Information and Operations Management, 3(1), 1-100.

Baker, M. J. (2000). Writing a literature review. The Marketing Review, 1, 219-247.

Balcik, B., Beamon, B. M., Krejci, C. C., Muramatsu, K. M., \& Ramirez, M. (2010). Coordination in humanitarian relief chains: Practices, challenges and opportunities. International Journal of Production Economics, $126(1), 22-34$.

Bhattacharya, S., Hasija, S., \& Wassenhove, L. N. (2014). Designing efficient infrastructural investment and asset transfer mechanisms in humanitarian supply chains. Production and Operations Management, 23(9), 1511-1521.

Blecken, A., Hellingrath, B., Dangelmaier, W., \& Schulz, S. F. (2009). A humanitarian supply chain process reference model. International Journal of Services Technology and Management, 12(4), 391.

Bölsche, D., Klumpp, M., \& Abidi, H. (2013). Specific competencies in humanitarian logistics education. In P. Tatham, \& N. Altay (Eds.), Journal of Humanitarian Logistics and Supply Chain Management, 3(2), 99-128.

Carroll, A., \& Neu, J. (2009). Volatility, unpredictability and asymmetry. In P. H. Tatham, (Ed.), Management Research News, 32(11), 1024-1037.

Chandes, J., \& Paché, G. (2010a). Investigating humanitarian logistics issues: From operations management to strategic action. In M. Leseure (Ed.), Journal of Manufacturing Technology Management, 21(3), 320-340.

Chandes, J., \& Pache, G. (2010). Strategizing humanitarian logistics: The challenge of collective action. Problems and Perspectives in Management, 8(1), 99-107.

Coles, J. B., Zhang, J., \& Zhuang, J. (2017). Bridging the research-practice gap in disaster relief: Using the IFRC Code of Conduct to develop an aid model. Annals of Operations Research. doi:10.1007/s10479017-2488-1.

Connelly, E. B., Lambert, J. H., \& Thekdi, S. A. (2016). Robust investments in humanitarian logistics and supply chains for disaster resilience and sustainable communities. Natural Hazards Review, 17(1), 1-11.

Cozzolino, A., Rossi, S., \& Conforti, A. (2012). Agile and lean principles in the humanitarian supply chain. Journal of Humanitarian Logistics and Supply Chain Management, 2(1), 16-33.

der Laan, E. A., Brito, M. P., \& Vergunst, D. A. (2009). Performance measurement in humanitarian supply chains. International Journal of Risk Assessment and Management, 13(1), 22.

der Laan, E. A., Brito, M. P., Fenema, P. C., \& Vermaesen, S. C. (2009). Managing information cycles for intra-organisational coordination of humanitarian logistics. International Journal of Services Technology and Management, 12(4), 362.

D’Haene, C., Verlinde, S., \& Macharis, C. (2015). Measuring while moving (humanitarian supply chain performance measurement-Status of research and current practice). Journal of Humanitarian Logistics and Supply Chain Management, 5(2), 146-161.

Diaz-Delgado, C., \& Gaytan Iniestra, J. (2014). Flood risk assessment in humanitarian logistics process design. Journal of Applied Research and Technology, 12(5), 976-984.

Dubey, R., Ali, S. S., Aital, P., \& Venkatesh, V. G. (2014). Mechanics of humanitarian supply chain agility and resilience and its empirical validation. International Journal of Services and Operations Management, 17(4), 367-384.

Dubey, R., \& Gunasekaran, A. (2015). The sustainable humanitarian supply chain design: Agility, adaptability and alignment. International Journal of Logistics Research and Applications, 19(1), 62-82.

Dubey, R., Singh, T., \& Gupta, O. K. (2015). Impact of agility, adaptability and alignment on humanitarian logistics performance: Mediating effect of leadership. Global Business Review, 16(5), 812-831.

DuHadway, S., Carnovale, S., \& Hazen, B. (2017). Understanding risk management for intentional supply chain disruptions: Risk detection, risk mitigation, and risk recovery. Annals of Operations Research. doi:10.1007/s10479-017-2452-0.

Ertem, M. A., Buyurgan, N., \& Rossetti, M. D. (2010). Multiple-buyer procurement auctions framework for humanitarian supply chain management. International Journal of Physical Distribution \& Logistics Management, 40(3), 202-227. 
Goffnett, S. P., Helferich, O. K., \& Buschlen, E. (2013). Integrating service-learning and humanitarian logistics education. In P. Tatham, \& N. Altay (Eds.), Journal of Humanitarian Logistics and Supply Chain Management, 3(2), 161-186.

Gralla, E., Goentzel, J., \& Chomilier, B. (2015). Case study of a humanitarian logistics simulation exercise and insights for training design. Journal of Humanitarian Logistics and Supply Chain Management, 5(1), $113-138$.

Haavisto, I., \& Goentzel, J. (2015). Measuring humanitarian supply chain performance in a multi-goal context. In D. B. Balcik (Ed.), Journal of Humanitarian Logistics and Supply Chain Management, 5(3), 300-324.

Haavisto, I., \& Kovács, G. (2014). Perspectives on sustainability in humanitarian supply chains. Disaster Prevention and Management: An International Journal, 23(5), 610-631.

Habib, M. S., Lee, Y. H., \& Memon, M. S. (2016). Mathematical models in humanitarian supply chain management: A systematic literature review. Mathematical Problems in Engineering, 2016(1), 1-20.

Hart, C. (1999). Doing a literature review: Releasing the social science research imagination. London: Sage.

Heaslip, G. (2013). Services operations management and humanitarian logistics. Journal of Humanitarian Logistics and Supply Chain Management, 3(1), 37-51.

Heaslip, G. (2015). Guest editorial: Humanitarian logistics-An opportunity for service research. Journal of Humanitarian Logistics and Supply Chain Management, 5(1), 2-11.

Heaslip, G., Sharif, A. M., \& Althonayan, A. (2012). Employing a systems-based perspective to the identification of inter-relationships within humanitarian logistics. International Journal of Production Economics, 139(2), 377-392.

Holgun-Veras, J., Jaller, M., \& Wachtendorf, T. (2012). Comparative performance of alternative humanitarian logistic structures after the Port-au-Prince earthquake: ACEs, PIEs, and CANs. Transportation Research Part A: Policy and Practice, 46(10), 1623-1640.

Holgun-Veras, J., Jaller, M., Wassenhove, L. N., Pérez, N., \& Wachtendorf, T. (2012). On the unique features of post-disaster humanitarian logistics. Journal of Operations Management, 30(7-8), 494-506.

Holgun-Veras, J., Pérez, N., Jaller, M., Wassenhove, L. N., \& Aros-Vera, F. (2013). On the appropriate objective function for post-disaster humanitarian logistics models. Journal of Operations Management, 31(5), 262280.

Holgun-Veras, J., Taniguchi, E., Jaller, M., Aros-Vera, F., Ferreira, F., \& Thompson, R. G. (2014). The Tohoku disasters: Chief lessons concerning the post disaster humanitarian logistics response and policy implications. Transportation Research Part A: Policy and Practice, 69(1), 86-104.

Iakovou, E., Vlachos, D., Keramydas, C., \& Partsch, D. (2014). Dual sourcing for mitigating humanitarian supply chain disruptions. Journal of Humanitarian Logistics and Supply Chain Management, 4(2), 245264.

Jabbour, C. J. (2013). Environmental training in organisations: From a literature review to a framework for future research. Resources, Conservation and Recycling, 74(1), 144-155.

Jahre, M., \& Fabbe-Costes, N. (2015). How standards and modularity can improve humanitarian supply chain responsiveness. In D. B. Balcik (Ed.), Journal of Humanitarian Logistics and Supply Chain Management, $5(3), 348-386$.

Jahre, M., \& Jensen, L.-M. (2010). Coordination in humanitarian logistics through clusters. In P. Tatham (Ed.), International Journal of Physical Distribution \& Logistics Management, 40(8/9), 657-674.

Jahre, M., Jensen, L.-M., \& Listou, T. (2009). Theory development in humanitarian logistics: A framework and three cases. In P. H. Tatham (Ed.), Management Research News, 32(11), 1008-1023.

Jensen, L.-M., \& Hertz, S. (2016). The coordination roles of relief organisations in humanitarian logistics. International Journal of Logistics Research and Applications, 19(5), 465-485.

John, L., Ramesh, A., \& Sridharan, R. (2012). Humanitarian supply chain management: A critical review. International Journal of Services and Operations Management, 13(4), 498.

Kabra, G., \& Ramesh, A. (2015). Analyzing drivers and barriers of coordination in humanitarian supply chain management under fuzzy environment. Benchmarking: An International Journal, 22(4), 559-587.

Kabra, G., \& Ramesh, A. (2015). Analyzing ICT issues in humanitarian supply chain management: A SAPLAP linkages framework. Global Journal of Flexible Systems Management, 16(2), 157-171.

Kabra, G., Ramesh, A., \& Arshinder, K. (2015). Identification and prioritization of coordination barriers in humanitarian supply chain management. International Journal of Disaster Risk Reduction, 13(1), $128-138$.

Kaur, H., \& Singh, S. P. (2016). Sustainable procurement and logistics for disaster resilient supply chain. Annals of Operations Research. doi:10.1007/s10479-016-2374-2, in press.

Kovács, G., \& Spens, K. (2009). Identifying challenges in humanitarian logistics. In: R. G. Richey (Ed.), International Journal of Physical Distribution \& Logistics Management, 39(6), 506-528.

Kovács, G., \& Spens, K. M. (2007). Humanitarian logistics in disaster relief operations. In M. Jahre (Ed.), International Journal of Physical Distribution \& Logistics Management, 37(2), 99-114. 
Kovacs, G., \& Spens, K. M. (2010). Knowledge sharing in relief supply chains. International Journal of Networking and Virtual Organisations, 7(2/3), 222.

Kovács, G., \& Spens, K. M. (2011). Humanitarian logistics and supply chain management: The start of a new journal. Journal of Humanitarian Logistics and Supply Chain Management, 1(1), 5-14.

Kovács, G., \& Spens, K. M. (2011). The journal of humanitarian logistics and supply chain management: First reflections. Journal of Humanitarian Logistics and Supply Chain Management, 1(2), 108-113.

Kovács, G., \& Spens, K. M. (2011). Trends and developments in humanitarian logistics-A gap analysis. In M. Crum (Ed.), International Journal of Physical Distribution \& Logistics Management, 41(1), 32-45.

Kovács, G., \& Tatham, P. (2009). Humanitarian logistics performance in the light of gender. International Journal of Productivity and Performance Management, 58(2), 174-187.

Kunz, N., \& Gold, S. (2017). Sustainable humanitarian supply chain management-exploring new theory. International Journal of Logistics Research and Applications, 20(2), 85-104.

Kunz, N., \& Reiner, G. (2012). A meta-analysis of humanitarian logistics research. Journal of Humanitarian Logistics and Supply Chain Management, 2(2), 116-147.

Kunz, N., Reiner, G., \& Gold, S. (2014). Investing in disaster management capabilities versus pre-positioning inventory: A new approach to disaster preparedness. International Journal of Production Economics, 157(1), 261-272.

Lage Junior, M., \& Godinho Filho, M. (2010). Variations of the kanban system: Literature review and classification. International Journal of Production Economics, 125(1), 13-21.

Leiras, A., de Brito Jr, I., Peres, E. Q., Bertazzo, T. R., \& Yoshizaki, H. T. (2014). Literature review of humanitarian logistics research: Trends and challenges. Journal of Humanitarian Logistics and Supply Chain Management, 4(1), 95-130.

L'Hermitte, C., Bowles, M., Tatham, P., \& Brooks, B. (2015). An integrated approach to agility in humanitarian logistics. Journal of Humanitarian Logistics and Supply Chain Management, 5(2), 209-233.

L'Hermitte, C., Tatham, P., Bowles, M., \& Brooks, B. (2016). Developing organisational capabilities to support agility in humanitarian logistics. Journal of Humanitarian Logistics and Supply Chain Management, 6(1), 72-99.

Liberatore, F., Ortuño, M. T., Tirado, G., Vitoriano, B., \& Scaparra, M. P. (2014). A hierarchical compromise model for the joint optimization of recovery operations and distribution of emergency goods in humanitarian logistics. Computers \& Operations Research, 42(1), 3-13.

Lima, F. S., de Oliveira, D., Goncalves, M. B., \& Samed, M. M. (2014). Humanitarian logistics: A clustering methodology for assisting humanitarian operations. Journal of Technology Management and Innovation, 9(2), 86-97.

Lu, Q., Goh, M., \& Souza, R. D. (2013). Learning mechanisms for humanitarian logistics. In P. Tatham, \& N. Altay (Eds.), Journal of Humanitarian Logistics and Supply Chain Management, 3(2), 149-160.

Mariano, E. B., Sobreiro, V., \& Rebelatto, D. A. (2015). Human development and data envelopment analysis: A structured literature review. Omega, 54(1), 33-49.

Matopoulos, A., Kovács, G., \& Hayes, O. (2014). Local resources and procurement practices in humanitarian supply chains: An empirical examination of large-scale house reconstruction projects. Decision Sciences, 45(4), 621-646.

McLachlin, R., \& Larson, P. D. (2011). Building humanitarian supply chain relationships: Lessons from leading practitioners. Journal of Humanitarian Logistics and Supply Chain Management, 1(1), 32-49.

Mulyono, N. B., \& Ishida, Y. (2014). Humanitarian logistics and inventory model based on probabilistic cellular automata. International Journal of Innovative Computing, Information and Control, 10(1), 357-372.

Oloruntoba, R., Hossain, G. F., \& Wagner, B. (2016). Theory in humanitarian operations research. Annals of Operations Research. doi:10.1007/s10479-016-2378-y.

Overstreet, R. E., Hall, D., Hanna, J. B., \& Rainer, R. K. (2011). Research in humanitarian logistics. Journal of Humanitarian Logistics and Supply Chain Management, 1(2), 114-131.

Ozkapici, D. B., Ertem, M. A., \& Aygüneş, H. (2016). Intermodal humanitarian logistics model based on maritime transportation in Istanbul. Natural Hazards, 83(1), 345-364.

Özpolat, K., Chen, Y., Hales, D., Yu, D., \& Yalcin, M. G. (2014). Using contests to provide business students project-based learning in humanitarian logistics: PSAid example. Decision Sciences Journal of Innovative Education, 12(4), 269-285.

Pateman, H., Hughes, K., \& Cahoon, S. (2013). Humanizing humanitarian supply chains: A synthesis of key challenges. The Asian Journal of Shipping and Logistics, 29(1), 81-102.

Pedraza-Martinez, A. J., Stapleton, O., \& Wassenhove, L. N. (2013). On the use of evidence in humanitarian logistics research. Disasters, 37(1), 51-67.

Prasad, S., Zakaria, R., \& Altay, N. (2016). Big data in humanitarian supply chain networks: A resource dependence perspective. Annals of Operations Research. doi:10.1007/s10479-016-2280-7. 
Rodrguez-Espndola, O., Albores, P., \& Brewster, C. (2016). GIS and optimisation: Potential benefits for emergency facility location in humanitarian logistics. Geosciences, 6(2), 18.

Şahin, A., Ertem, M. A., \& Emür, E. (2014). Using containers as storage facilities in humanitarian logistics. Journal of Humanitarian Logistics and Supply Chain Management, 4(2), 286-307.

Santarelli, G., Abidi, H., Klumpp, M., \& Regattieri, A. (2015). Humanitarian supply chains and performance measurement schemes in practice. International Journal of Productivity and Performance Management, 64(6), 784-810.

Schiffling, S., \& Piecyk, M. (2014). Performance measurement in humanitarian logistics: A customer-oriented approach. Journal of Humanitarian Logistics and Supply Chain Management, 4(2), 198-221.

Sheller, M. (2012). The islanding effect: Post-disaster mobility systems and humanitarian logistics in Haiti. Cultural Geographies, 20(2), 185-204.

Sheppard, A., Tatham, P., Fisher, R., \& Gapp, R. (2013). Humanitarian logistics: Enhancing the engagement of local populations. Journal of Humanitarian Logistics and Supply Chain Management, 3(1), 22-36.

Sushil. (2017). Theory building using SAP-LAP linkages: An application in the context of disaster management. Annals of Operations Research. doi:10.1007/s10479-017-2425-3.

Tabaklar, T., Halldórsson, Á., Kovács, G., \& Spens, K. (2015). Borrowing theories in humanitarian supply chain management. In D. B. Balcik (Ed.), Journal of Humanitarian Logistics and Supply Chain Management, 5(3), 281-299.

Tatham, P. (2012). Some reflections on the breadth and depth of the field of humanitarian logistics and supply chain management. Journal of Humanitarian Logistics and Supply Chain Management, 2(2), 108-111.

Tatham, P., \& Houghton, L. (2011). The wicked problem of humanitarian logistics and disaster relief aid. Journal of Humanitarian Logistics and Supply Chain Management, 1(1), 15-31.

Tatham, P., \& Kovács, G. (2010). The application of "swift trust" to humanitarian logistics. International Journal of Production Economics, 126(1), 35-45.

Tatham, P., \& Spens, K. (2011). Towards a humanitarian logistics knowledge management system. Disaster Prevention and Management: An International Journal, 20(1), 6-26.

Tatham, P., \& Spens, K. (2015). Cracking the humanitarian logistic coordination challenge: Lessons from the urban search and rescue community. Disasters, 40(2), 246-261.

Tofighi, S., Torabi, S. A., \& Mansouri, S. A. (2016). Humanitarian logistics network design under mixed uncertainty. European Journal of Operational Research, 250(1), 239-250.

Trestrail, J., Paul, J., \& Maloni, M. (2009). Improving bid pricing for humanitarian logistics. In R. G. Richey (Ed.), International Journal of Physical Distribution \& Logistics Management, 39(5), 428-441.

UNISDR. (2016). Impacts of disasters since the 1992 Rio de Janeiro Earth Summit.

Vaillancourt, A. (2016). A theoretical framework for consolidation in humanitarian logistics. Journal of Humanitarian Logistics and Supply Chain Management, 6(1), 2-23.

Vaillancourt, A. (2016). Kit management in humanitarian supply chains. International Journal of Disaster Risk Reduction, 18(1), 64-71.

Vega, D., \& Roussat, C. (2015). Humanitarian logistics: The role of logistics service providers. In D. B. Gammelgaard (Ed.), International Journal of Physical Distribution \& Logistics Management, 45(4), 352-375.

Wassenhove, L. N. (2006). Humanitarian aid logistics: Supply chain management in high gear. Journal of the Operational Research Society, 57(5), 475-489.

Wassenhove, L. N., \& Martinez, A. J. (2012). Using OR to adapt supply chain management best practices to humanitarian logistics. International Transactions in Operational Research, 19(1-2), 307-322.

Yadav, D. K., \& Barve, A. (2015). Analysis of critical success factors of humanitarian supply chain: An application of interpretive structural modeling. International Journal of Disaster Risk Reduction, 12(1), 213-225.

Yadav, D. K., \& Barve, A. (2016). Modeling post-disaster challenges of humanitarian supply chains: A TISM approach. Global Journal of Flexible Systems Management, 17(3), 321-340.

Yang, F., Yuan, Q., Du, S., \& Liang, L. (2014). Reserving relief supplies for earthquake: A multi-attribute decision making of China Red Cross. Annals of Operations Research, 247(2), 759-785.

Yang, H., Yang, L., \& Yang, S.-H. (2011). Hybrid Zigbee RFID sensor network for humanitarian logistics centre management. Journal of Network and Computer Applications, 34(3), 938-948.

Ye, Y., \& Liu, N. (2014). Humanitarian logistics planning for natural disaster response with Bayesian information updates. Journal of Industrial and Management Optimization, 10(3), 665-689. 